\title{
Characteristic MRI and funduscopic findings help diagnose ARSACS outside Quebec
}

Figure MRI
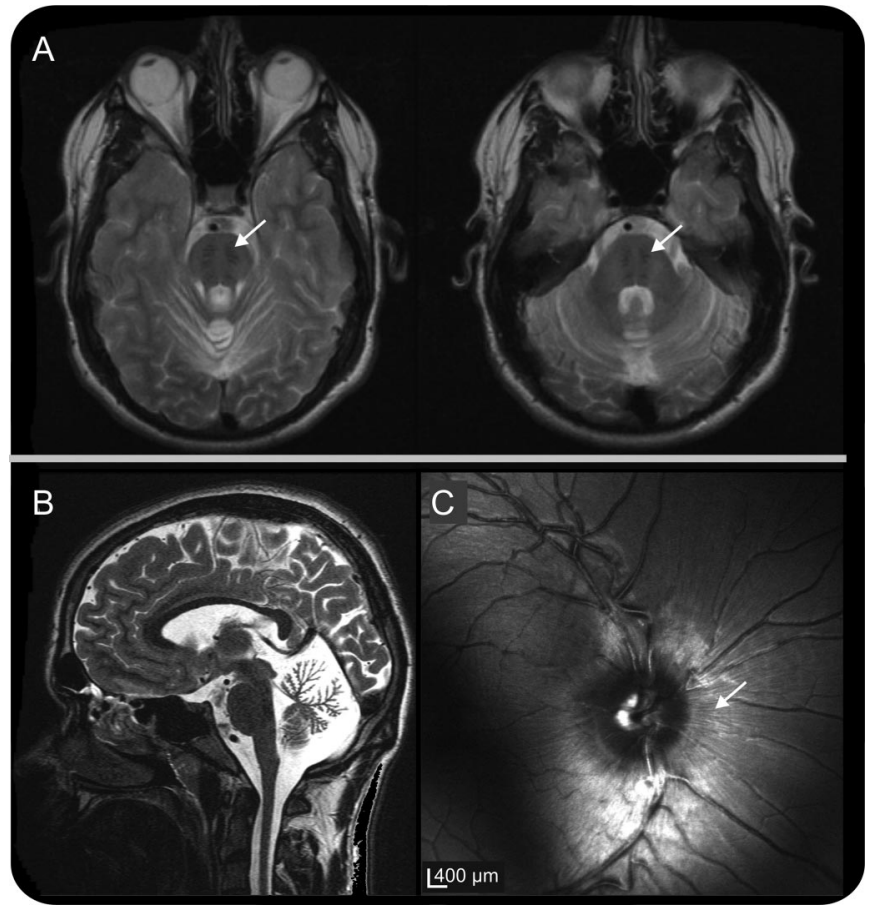

(A) T2-weighted MRI shows linear hypointensities near the pyramidal tract in the pons on transversal slices and (B) cerebellar atrophy, predominantly of the superior vermis on sagittal slices. (C) Funduscopy shows myelinated fibers radiating from the optic disk.

A 20-year-old German man had progressive ataxia, spasticity, and polyneuropathy from childhood. MRI revealed linear pontine hypointensities (figure, A) and cerebellar atrophy (figure, B). Funduscopy showed myelinated fibers radiating from the optic disc (figure, C). Autosomal recessive spastic ataxia Charlevoix-Saguenay (ARSACS) was diagnosed by identification of biallelic SACS gene mutations (chromosome 13q12). The gene product is sacsin, found in large neurons such as Purkinje cells, one of many ataxia-related proteins. ARSACS, first described in the French-Canadian founder population of Quebec, occurs outside Quebec, ${ }^{1,2}$ suggesting that worldwide screening in early-onset cerebellar ataxia with characteristic pontine and funduscopic abnormalities may identify additional cases.

M. Gerwig, MD, Essen; S. Krüger, MD, F.R. Kreuz, MD, Dresden; S. Kreis, MD, Essen; E.R. Gizewski, MD, Essen and Giessen; D. Timmann, MD, Essen, Germany

Disclosure: Dr. Gerwig and Dr. Krüger report no disclosures. Dr. Kreuz is the head of the Scientific Board of the Deutsche Heredo-Ataxie Gesellschaft e.V. (DHAG). Dr. Kreis and Dr. Gizewski report no disclosures. Dr. Timmann serves on the Medical Board of the DHAG and the Society for the Research on the Cerebellum; serves on the editorial advisory board of Gait \& Posture and as a Section Editor for The Cerebellum and for InFo Neurologie \& Psychiatrie; and receives research support from Merck Sharp \& Dohme Corp., the German Research Foundation (DFG), The European Union, the Bernd Fink Foundation, and the German Heredoataxia Foundation.

Address correspondence and reprint requests to Dr. Marcus Gerwig, Department of Neurology, University of Duisburg-Essen, Hufelandstrasse 55, D-45147 Essen, Germany; marcus.gerwig@uk-essen.de

1. Vermeer S, Meijer RP, Pijl BJ, et al. ARSACS in the Dutch population: a frequent cause of early-onset cerebellar ataxia. Neurogenetics 2008;9:207-214.

2. Anheim M, Fleury M, Monga B, et al. Epidemiological, clinical, paraclinical and molecular study of a cohort of 102 patients affected with autosomal recessive progressive cerebellar ataxia from Alsace, Eastern France: implications for clinical management. Neurogenetics 2010;11:1-12. 


\section{Neurology}

\section{Characteristic MRI and funduscopic findings help diagnose ARSACS outside Quebec M. Gerwig, S. Krüger, F.R. Kreuz, et al. Neurology 2010;75;2133 \\ DOI 10.1212/WNL.0b013e318200d7f8}

\section{This information is current as of December 6, 2010}

\section{Updated Information \& Services}

References

Citations

Subspecialty Collections

Permissions \& Licensing

\section{Reprints}

including high resolution figures, can be found at: http://n.neurology.org/content/75/23/2133.full

This article cites 2 articles, 0 of which you can access for free at: http://n.neurology.org/content/75/23/2133.full\#ref-list-1

This article has been cited by 2 HighWire-hosted articles: http://n.neurology.org/content/75/23/2133.full\#\#otherarticles

This article, along with others on similar topics, appears in the following collection(s):

\section{All Genetics}

http://n.neurology.org/cgi/collection/all_genetics

\section{Cerebellum}

http://n.neurology.org/cgi/collection/cerebellum

Gait disorders/ataxia

http://n.neurology.org/cgi/collection/gait_disorders_ataxia

MRI

http://n.neurology.org/cgi/collection/mri

Peripheral neuropathy

http://n.neurology.org/cgi/collection/peripheral_neuropathy

Information about reproducing this article in parts (figures,tables) or in its entirety can be found online at:

http://www.neurology.org/about/about_the_journal\#permissions

Information about ordering reprints can be found online:

http://n.neurology.org/subscribers/advertise

Neurology ${ }^{\circledR}$ is the official journal of the American Academy of Neurology. Published continuously since 1951, it is now a weekly with 48 issues per year. Copyright Copyright (? 2010 by AAN Enterprises, Inc.. All rights reserved. Print ISSN: 0028-3878. Online ISSN: 1526-632X.

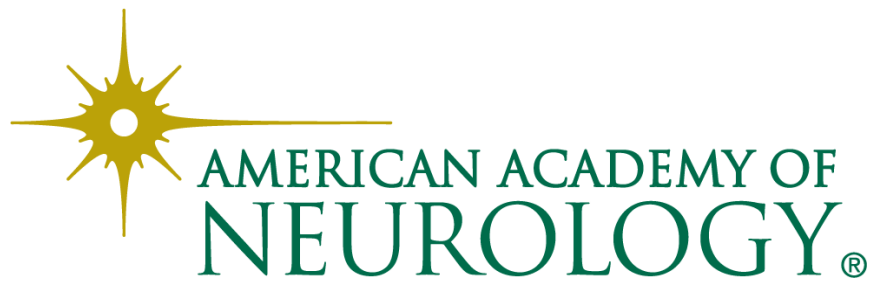

